\title{
Relationship between Financial Distress, Demographics and General Family Functioning in Turkey
}

\author{
Ayfer AYDINER BOYLU iD a Gülay GÜNAY iD b Cengiz KILIÇ iD c \\ a Hacettepe University, Faculty of Economics and Administrative Sciences, Ankara, Turkey. ayfer boylu@hotmail.com \\ b Karabük University, Faculty of Economics and Administrative Sciences, Karabük, Turkey. glygunay@gmail.com \\ c Atatürk University, Open Education Faculty, Erzurum, Turkey. cengizkilic@atauni.edu.tr
}

\begin{tabular}{|c|c|}
\hline ARTICLE INFO & ABSTRACT \\
\hline Keywords: & $\begin{array}{l}\text { Purpose - The purpose of this study is to explore the relationship between financial distress, and } \\
\text { general family functioning, including the effect of demographic factors and financial behaviors, } \\
\text { based on a sample of families from Turkey. }\end{array}$ \\
\hline $\begin{array}{l}\text { Financial Distress } \\
\text { General Family Functioning } \\
\text { Financial Well-Being }\end{array}$ & $\begin{array}{l}\text { Design/methodology/approach - Participants in this study were employees of the Hacettepe } \\
\text { University ( } \mathrm{n}=1400 \text { ). Data were collected through a demographic information form, a questionnaire } \\
\text { on financial behaviors (budgeting, saving, and borrowing) of the participating families, InCharge } \\
\text { Financial Distress/Financial Well-Being Scale (IFDFW) and the General Functioning Subscale of the } \\
\text { McMaster Family Assessment Device (McMaster FAD). }\end{array}$ \\
\hline $\begin{array}{l}\text { Received } 22 \text { September } 2019 \\
\text { Revised } 18 \text { December } 2019 \\
\text { Accepted } 25 \text { December } 2019\end{array}$ & $\begin{array}{l}\text { Findings - The results indicated that better family functioning is strongly associated with smaller } \\
\text { households. In addition, financial distress is significantly correlated with lower general functioning } \\
\text { in families. It is clear that the size of the family and financial distress are important variables on } \\
\text { general family functioning. }\end{array}$ \\
\hline $\begin{array}{l}\text { Article Classification: } \\
\text { Research Article }\end{array}$ & $\begin{array}{l}\text { Discussion - It is clear that financial behaviors are related to financial distress and important for } \\
\text { maintaining better general family functioning. The lack of financial management competency has a } \\
\text { more significant influence on financial distress than income poverty. Therefore education about } \\
\text { financial matters is a significant determinant of financial strain and related training programs should } \\
\text { designed to increase financial well-being. }\end{array}$ \\
\hline
\end{tabular}

\section{Introduction}

Family is indispensable for human life. (Bulut 1990:1). It is a universal institution that is the protector and transmitter of cultural identity, human values, and historical continuity in communities. This makes a family virtually indispensable for the preservation of human culture. Continuity of the family resides on the foundation of the fulfillment of certain family functions. Although some characteristics of the family change as society changes, it retains several unique and critical functions (Şimşek 2009). The main function of the family is to ensure the social, psychological and biological development of family members (Epstein et al. 1982).

In the relevant literature, there are various models for identifying and evaluating the functions of a family, such as the Circumplex Model of Family Functioning (Olson 2000), the Beavers Family Systems Model (Beavers and Hampson 2000), and the McMaster Model of Family Functioning (Epstein et al. 1978). The Circumplex Model of Family Functioning (Olson, 2000) describes families along three dimensions: cohesion, adaptability and communication. The Beavers Family Systems model (Beavers and Hampson, 2000) contains two dimensions: family competence and family style. The McMaster Model of Family Functioning (Epstein et al, 1978) describes families along six interrelated dimensions: problem solving, communication, roles, affective responsiveness, affective expression and behaviour control. Drumm et al. (2000) stated that these three scales can be used in the assessment of families. However, it is clear that McMaster Family Assessment Scale is the most detailed scale for evaluating families.

The Family Assessment Device (FAD), which is based on the McMaster Model of Family Functioning, was used in this study. In this model, a healthy family must fulfill six basic functional dimensions: problem solving, 


\section{A. Aydıner Boylu - G. Günay - C. Kılıç 11/4 (2019) 3385-3403}

communication, affective responsiveness, affective involvement, roles, and behavior control (Miller et al. 1985). An effectively functioning family is expected to be able to deal with each dimension successfully (Epstein et al. 1984). Lewis et al. (1976) defined functional/non-functional families depending on whether they were able to fulfill specific functions at an expected level. The definition of a healthy or effectively functioning family according to the McMaster Model of Family Functioning is summarized as follows: a healthy family solves problems quickly and easily, communicates in a clear and direct manner, has reasonable roles and does not overburden anyone, has the capacity to respond with the full range of emotions, has empathic involvement in particular activities and interests of individual family members, and has flexible behavior control (Ryan et al. 2005:26-38). There is a positive relationship between family functioning level and life satisfaction and happiness. According to Botha and Booysen (2014), families with moderate or balanced family functions are happier than families with high or moderate dysfunction.

\subsection{Demographic Variables}

The literature emphasizes that there are many factors that affect whether families are functionally healthy or unhealthy. Such as the number of household members; the number of children; composition of family members, for example, their age, gender structure, and education level; family type; employment of adult family members; and income level of the family (Hossain 2001; McCreary and Dancy 2004; Mandara and Murray 2000; Bilen 2004:135; Fişek 1992:293; Bulut 1993; Gökçe 1990:214). In the study by Hossain (2001) mothers stated greater commitment, cohesion, and communication than fathers. Çakıcı (2006:97) found a significant relationship between family functioning and males' ages. Also females' ages is significantly related to solving problems in the family (Ersoy 1997). Parents with higher education levels were more compatible and open-minded, provided a more positive family atmosphere, and better general family relationships (Çakıcı 2006:101-105; Şimşek 2009; İnci 2008:38). The family functioning is better in two-parent families than in single-parent families (Clark et al. 2000; Yeung and Chan 2010; Pettit et al. 2001; Wang et al. 2015). Research has also shown that the type of family is effective in terms of family functions. (Nazlı 1997; İmamoğlu 1991; İnci 2008:42). The communication in nuclear families is greater than traditional family types. In addition, an increase in the number of family members has negative effects on many functions (İnci 2008:42).

Income level is directly related to the level of health, education, housing and living conditions (Ormsby and Fairchild 1987). Worries about money endanger and disrupt the normal functioning of the family system as a whole (Walsh 2003). Şimşek (2009) found a positive correlation between income level and family functioning. Also in Aydıner Boylu and Günays' (2013) study, family functioning found to be significantly higher in families, whose being satisfied with income level. The negative impact of financial distress on family relationships is evident in the literature, such as diminished relationships due to strained interactions and disruptions and changes in social activities, support, and networks (Conger et al. 1992; Elder and Caspi 1988; Tschann et al. 1989; Voydanoff 1990; Gershoff et al. 2007; Fine and Fincham 2013:338; Friedman and Thomas 2008; Aytaç and Rankin 2008).

There is also clear evidence of the debilitating effect of economic stress on marital relationships. The quality of a marriage is impacted by economic stress, which increases negative exchanges and reduces positive exchanges between spouses and can lead to factors such as lowered self-esteem, reduced warmth, increased hostility, and competitiveness between the spouses (Conger et al. 1990a, 1990b; Lempers and Clark-Lempers 1997; Ho et al. 1995; Liker and Elder 1983; Pittman and Lloyd 1988). Additionally, this stress contributes to a higher risk of violence against the partner. In addition, this stress increases the risk of violence against the spouse. Long-term poverty leads to various criminal behaviors among parents. (McLoyd 1990; Hashima and Amato 1994; Fox et al. 2002).

These negative effects are not limited to marital relationships, but are also related to parenting, reduced affective support, declining quality of parent-child relationships, more negative child development outcomes such as less nurturance, and more inconsistent and arbitrary discipline toward children (Elder and Caspi 1988; Elder et al. 1992; Lempers et al. 1989; Gelles 1989; McLoyd and Wilson 1991; Elder et al. 1985; Conger et. al. 1992). For example, Gelles and Straus (1979) found that the rate of violence against children of the parents who have income below the poverty level is much higher. Dodge et al. (1994) and Papp et al. (2009) also indicated that parents who suffered long-term economic distress were more frequently coercive and punitive in their parenting styles. 


\section{A. Aydıner Boylu - G. Günay - C. Kılıç 11/4 (2019) 3385-3403}

Moreover, it is determined that economic pressures in the form of economic crisis and unemployment leads to significant changes in family life and lifestyles such as their consumption expenditures and behaviour styles (Kaya 2002). Lifestyle includes all aspects of family life such as accommodation, food, education, health, entertainment, transportation, communication and so on, and expresses the financial, normative, behavioural, cognitive dimensions of these aspects. In a situation where basic requirements cannot be met as a result of economic pressures, people can go through emotional insecurity and face tremendous amount of attrition. A number of people experience anger, fatigue, insomnia, and anorexia (Ha and Kang 2013).

Hypothesis 1: Demographic variables will be significantly related to General Family Functioning.

\subsection{Financial Behaviors}

The behaviors related to budgeting, saving and borrowing as well as the level of income affect the social and economic welfare of family (Çopur and Şafak 2000). Budgeting is increasingly necessary to survive in the present economy and crucial in families financial management. Beutler and Mason (1987) found a modest positive relationship between families' budget formality and their net worth. Families who has financial plans, record keeping systems, and who had planning horizons reported significantly higher net worth than other families. Saving is necessary for future expenses or to meet financial emergencies and also is a tool to protect families from financial crisis (Lee et al. 2000; Sumarwan and Hira 1992). Borrowing is another important behavior for family well-being. Borrowing can contribute to welfare by enabling families to purchase goods and services that they cannot obtain with their current income. However, on the other hand, it may also lead to unnecessary consumption and reduced savings (Aydıner Boylu et al. 2007).

Hypothesis 2: Financial behaviors will be significantly related to General Family Functioning.

\subsection{Financial Distress}

Although objective indicators, such as income levels, are used to predict a family's perceptions of their financial situation (Walson and Fitzsimmons 1993), they do not measure one's emotions or reactions in depth. For example, two individuals with the same income level may have different perceptions about their financial situation, as their consumption values and spending habits may be different. In addition, although an individual is very unhappy about his / her financial situation, another individual with the same income level can be quite happy about it. This difference is defined as perceived income adequacy. Perceived income adequacy considers not only the income level, but also the perceptions of how well this income meets the needs of the family (Danes and Rettig 1995). The terms used to describe a person's feelings about his / her financial situation are varied. One of these term financial distress has been described as judgments about and responses to one's financial condition (Prawitz et al. 2006). Financial distress can last a short time or can become a persistent state (Garman et al. 2004).

The researchers stated that specific subjective measures can also be used to predict the opinions of individuals about their financial conditions (Walson and Fitzsimmons 1993; Joo and Grable 2004). For example, Joo and Grable (2004) observed that subjective measures, such as reported levels of financial stress and risk tolerance, are related to financial satisfaction.

\section{Hypothesis 3: Financial distress will be significantly related to General Family Functioning.}

The functions of the family are of great importance as they cannot be carried out by another entity as successfully and consistently as a family. However, financial distress prevents families from functioning successfully. Despite the importance of family as a societal entity, no former study has directly focused on the influence of financial distress on family functioning. This study was designed to complete the shortcomings in this subject by determining (1) the relationship between demographic characteristics and the general functioning, (2) the relationship between financial behaviors and the general functioning, (3) and also the relationship between financial distress and general functioning.

\section{Method}

\subsection{Research model}

This study has been planned on the basis of qualitative research method and has been made considering the general screening model. General screening models are screening models made from a universe, which has 


\section{A. Aydıner Boylu - G. Günay - C. Kılıç 11/4 (2019) 3385-3403}

more than one element, in the whole universe or a group, sample or sample taken from the universe in order to reach a general idea about the state of the universe. The relational screening model is a research model aiming to determine the existence of the change between two or more variables and the extent of change, if any (Karasar, 2007).

\subsection{Participants}

The data of the study were collected in Hacettepe University (HU) using a cross-sectional questionnaire, which including staff living in different district which represent the different socio-economic levels. Hacettepe University has about 33823 undergraduate students and about 8615 postgraduate students. As of May 2014, there were 9477 staff. Data were collected as a result of interviews with 1624 staff. Incomplete and incorrectly filled questionnaires were not included in the study (224 questionnaires). Finally, a total of 1400 (468 academic staff, 621 administrative staff, 98 technical staff, 26 medical staff, and 187 auxiliary staff) interviews were conducted. The participation was $86.2 \%$.

\subsection{Procedure}

At first, necessary negotiations were held with Hacettepe University Rectorate for this research and permissions necessary for the institution were taken officially in the survey process of study. For the access of staff to be taken to the scope of study, academic, administrative, technical, medical, and auxiliary staff lists taken from Hacettepe University Directorate of Personnel Department were used. Each individual willing to participate in the study was interviewed separately. Individuals who refused to participate were not included in the study $(n=131)$. The participants were informed about the aim of the study and how the questionnaire should be completed. The participants were asked to complete the questionnaire within three days. The researcher worked with groups of participants over a two-month period between June and August 2014.

\subsection{Measurement Variables}

\section{Independent Variables}

\section{Demographic Variables}

The study included demographic variables such as gender, age, education, working status, marital status, family monthly income, family type, and number of family members.

The respondents in this study included 703 women (50.2\%) and 697 men (49.8\%). Their average age was 36.7 $(S D=9.2)$ (Women: $M=35.2 S D=8.4$; Men: $M=38.2, S D=9.7)$. Of the participants, $33.3 \%$ were below 31 years of age. The participants' education level varied between 8 and 19 years, and average education level was 14.4 years $(S D=3.2)$. The participants had a college education rank first $(25.4 \%)$ followed by secondary education $(18.6 \%)$, master's degree (18.2\%), high school education (15.6\%), and bachelor's degree (15.0\%). Monthly incomes varied between 1.100,00 and 13.500,00 TL (\$519 and \$6368) and average monthly income was 3.292,00 TL (\$1553) ( $S D=1.7)$ (one dollar was equivalent to about $2.12 \mathrm{TL}$ in June 2014). 41.7\% of the participant's income was $3501 \mathrm{TL}$ or above ( $\$ 1,652$ or more). Of the participants, $44.4 \%$ were working as administrative staff, $33.4 \%$ were academic staff, $13.3 \%$ were auxiliary staff, $7.0 \%$ were technical staff, and $1.9 \%$ were medical staff (Table 1).

More than half $(64.7 \%)$ of the participants were married. The proportion of nuclear families was the highest (89.1\%). Also, there were proportionally more people living in families with three $(32.4 \%)$ or four $(32.7 \%)$ members than the other family configurations $(M=3.6 ; S D=1.1)$ (Table 1$)$. 
Table 1 Characteristics of The Sample

\begin{tabular}{|c|c|c|}
\hline Demographic Variables & $N$ & $\%$ \\
\hline \multicolumn{3}{|l|}{ Gender } \\
\hline Woman & 703 & 50.2 \\
\hline Man & 697 & 49.8 \\
\hline \multicolumn{3}{|l|}{ Age $(M=36.7 ; S D=9.2)$} \\
\hline$\leq 30$ & 466 & 33.3 \\
\hline $31-40$ & 465 & 33.2 \\
\hline $41-50$ & 365 & 26.1 \\
\hline$\geq 51$ & 104 & 7.4 \\
\hline \multicolumn{3}{|c|}{ Monthly family income ( $M=3.292,00$ TL ( $\$ 1553) ; S D=1.7)$} \\
\hline 2000 TL or less ( $\$ 943$ or less) & 359 & 25.6 \\
\hline $2001 \mathrm{TL}-3500 \mathrm{TL}(\$ 943-\$ 1,651)$ & 457 & 32.7 \\
\hline $3501 \mathrm{TL}$ or more ( $\$ 1,652$ or more) & 584 & 41.7 \\
\hline \multicolumn{3}{|l|}{ Education $(M=14.4 ; S D=3.2)$} \\
\hline Secondary education (8 years) & 260 & 18.6 \\
\hline High school education (11 years) & 218 & 15.6 \\
\hline College (13 years) & 356 & 25.4 \\
\hline Bachelor's degree (15 years) & 210 & 15.0 \\
\hline Master's degree (17 years) & 255 & 18.2 \\
\hline PhD degree (19 years) & 101 & 7.2 \\
\hline \multicolumn{3}{|l|}{ Working status } \\
\hline Academic staff & 468 & 33.4 \\
\hline Administrative staff & 621 & 44.4 \\
\hline Technical staff & 98 & 7.0 \\
\hline Medical staff & 26 & 1.9 \\
\hline Auxiliary staff & 187 & 13.3 \\
\hline \multicolumn{3}{|l|}{ Marital status } \\
\hline Single & 445 & 31.8 \\
\hline Married & 906 & 64.7 \\
\hline Widowed/Divorced & 49 & 3.5 \\
\hline \multicolumn{3}{|l|}{ Family type } \\
\hline Nuclear family & 1247 & 89.1 \\
\hline Extended family & 101 & 7.2 \\
\hline Single parent family & 52 & 3.7 \\
\hline \multicolumn{3}{|l|}{ Number of family members $(M=3.6 ; S D=1.1)$} \\
\hline 2 members & 237 & 16.9 \\
\hline 3 members & 453 & 32.4 \\
\hline 4 members & 458 & 32.7 \\
\hline 5 members & 179 & 12.8 \\
\hline 6 members & 50 & 3.6 \\
\hline 7 or more members & 23 & 1.6 \\
\hline
\end{tabular}

Financial Behaviors

Briefly, financial behavior is for the welfare of individuals and family members (Günay et al. 2014). Behavior can be measured as a binary variable, i.e., whether or not the behavior was exhibited (Xiao 2008). In this study, questions on financial behavior has been developed by researcher and consists of four questions about budgeting, saving, and borrowing. Budgeting was measured by asking the question "Are you using a budget to manage your income?" ( $1=$ yes, $0=$ no). Saving was examined by asking the question "Are you able to save some of your income?" $(1=$ yes, $0=$ no). Borrowing was evaluated by asking two questions: "Are you in debt?" ( 1 = never, 2 = sometimes, 3 = always) and "What is your reason for borrowing?" ( 1 = maintaining current expenditures, 2 = investing). 
The In Charge Financial Distress/Financial Well-Being (IFDFW) scale was developed by Prawitz et al. (2006) to measure financial distress/well-being. The scale evaluates a latent construct representing responses to one's financial state on a continuum ranging from overwhelming financial distress (the lowest level of financial wellbeing) to no financial distress (the highest level of financial well-being). The IFDFW scale includes eight questions, including "What do you feel is the level of your financial stress today?" and "How satisfied you are with your present financial situation". Responses are given on a 10-point Likert scale ranging from negative (1) to positive (10) $(1$ = very dissatisfied to $10=$ very satisfied $)$. Individual scores can range from 8 ( 1 point on each question) to 80 (10 points on each question). Scores on the IFDFW are computed by adding numerical responses for each of the eight items and then dividing the total by eight. The resulting scores can range from 1 (overwhelming financial distress) to 10 (no financial distress), indicating that a lower level of financial distress results in a higher score on the scale. The Cronbach Alpha coefficient is found to be. 96 (Prawitz et al. 2006).

The IFDFW scale was adapted to the Turkish culture by Gutter and Copur in 2011. The factor analysis applied by Gutter and Copur (2011) showed that the results matched well with those of Prawitz et al. (2006). Adaptation studies of the IFDFW scale for Turkish culture had sufficiently high reliability and validity to justify its use as a tool to measure Turkish families' financial distress. Reliability analyses showed that the IFDFW scale had a high internal consistency (Cronbach Alpha: .82). Turkish family scores ranged from 1 (overwhelming financial distress) to 8.75 (no financial distress). The average financial distress score for Turkish families was $4.40(S D=1.47)$, with a median of 4.50 , which provided an indication of the average level of financial distress (Gutter and Copur 2011).

In this study, the IFDFW scale Cronbach Alpha was .92. The IFDFW scale median score was $5.51(S D=2.02)$ and the scale scores ranged from 1 (overwhelming financial distress) to 9.63 (no financial distress). Table 2 presented Mean, Standard Deviation, Minimum, Maximum value of responses to each of the questions on which the IFDFW Scale indexes are based.

\section{Dependent Variables}

\section{McMaster FAD}

The FAD was developed to measure perceptions of family functioning. The FAD is based on the McMaster Model of Family Functioning and emphasizes a functional approach to understanding whether families accomplish the basic tasks of daily life (Epstein et al. 1978). It measures six dimensions of the McMaster of Family Functioning Model. In addition to these six subscales, a 12-item, General Functioning Subscale, which "assesses the overall level of family functioning," is included in the FAD (Epstein et al. 1983). In order to evaluate the general functioning level of a family, this study use this subdimension to gather information about all dimensions-problem solving, communication, roles, affective responsiveness, affective involvement, and behavior control - of the scale. With specific reference to the General Functioning Subscale (GF) of the FAD, the previous research have reported that the GF subscale has high psychometric properties and internal consistency to obtain a global picture of family functioning (Byles et al. 1988; Miller et al. 1985; Epstein et al. 1983). Also this subscale shortens the items in the questionnaire which make easier for participants to fill the form. From that, in this study GF subscale was used to measure family functioning instead of the longer version of Family Assessment Device.

The FAD is a self-reporting questionnaire where each question is answered on a 4-point scale ( 1 represents strongly agree and 4 represents strongly disagree). The FAD is scored by summing the endorsed responses (1-4) and dividing by the number of items in the scale. The scores range from 1.0 (best functioning) to 4.0 (worst functioning), indicating that higher scores represent less satisfaction with family functioning (Miller et al. 1985). 
Table 2 The in Charge Financial Distress/Financial Well-Being Scale, Mean, Standard Deviation, Minimum, Maximum

\begin{tabular}{|c|c|c|c|c|}
\hline Items & $M$ & $S D$ & Minimum & Maximum \\
\hline 1. What do you feel is the level of your financial stress today? & 5.6 & 2.3 & 1 & 10 \\
\hline 2. How satisfied you are with your present financial situation? & 5.1 & 2.4 & 1 & 10 \\
\hline 3. How do you feel about your current financial situation? & 5.1 & 2.2 & 1 & 10 \\
\hline $\begin{array}{l}\text { 4. How often do you worry about being able to meet normal monthly } \\
\text { living expenses? }\end{array}$ & 5.1 & 2.4 & 1 & 10 \\
\hline $\begin{array}{l}\text { 5. How confident are you that you could find the money to pay for a } \\
\text { financial emergency that costs about } \$ \mathbf{1 , 0 0 0} \text { ? }\end{array}$ & 6.7 & 3.1 & 1 & 10 \\
\hline $\begin{array}{l}\text { 6. How often does this happen to you? You want to go out to eat, go to a } \\
\text { movie or do something else and don't go because you can't afford to? }\end{array}$ & 6.0 & 2.8 & 1 & 10 \\
\hline $\begin{array}{l}\text { 7. How frequently do you find yourself just getting by financially and } \\
\text { living paycheck to paycheck? }\end{array}$ & 4.8 & 2.7 & 1 & 10 \\
\hline 8. How stressed do you feel about your personal finances in general? & 5.7 & 2.3 & 1 & 10 \\
\hline
\end{tabular}

Table 3 McMaster FAD General Functioning Subscale, Mean, Standard Deviation, Minimum, Maximum

\begin{tabular}{lcccc}
\hline Items & $M$ & $S D$ & Minimum & Maximum \\
\hline 1. Planning family activities is difficult because we & & & & \\
misunderstand each other & 1.8 & 1.0 & 1 & 4 \\
2. In time of crisis we can turn to each other for support & 1.3 & .7 & 1 & 4 \\
3. We cannot talk to each other about sadness we feel & 1.6 & .9 & 1 & 4 \\
4. Individuals are accepted for what they are & 1.6 & .8 & 1 & 4 \\
5. We avoid discussing our fears and concerns & 1.6 & .9 & 1 & 4 \\
6. We can express feelings to each other & 1.8 & .9 & 1 & 4 \\
7. There are lots of bad feelings in the family & 1.4 & .7 & 1 & 4 \\
8. We feel accepted for what we are & 1.5 & .8 & 1 & 4 \\
9. Making decisions is a problem for our family & 1.6 & .8 & 1 & 4 \\
10. We are able to make decisions about how to solve & 1.9 & .9 & 1 & 4 \\
problems & 1.3 & .7 & 1 & 4 \\
11. We don't get along well together & 1.3 & .6 & 1 & 4 \\
12. We confide in each other & & & & 4 \\
\hline
\end{tabular}

A study for Turkish validity and reliability of the scale was conducted by Bulut (1990). The reliability study was examined for internal consistency and point invariance, and the scale was tested for construct validity and compliance validity. The correlation coefficient calculated for the subscales of the general functions was .66. This finding confirms that the psychometric properties of the scale are at a sufficient level. In this study, the internal consistency coefficient of the General Functioning Subscale was calculated as .71. Table 3 presented Mean, Standard Deviation, Minimum, Maximum value of responses to each of the questions on which the General Functioning Subscale indexes are based.

\subsection{Preliminary Analysis}

The scope of validity and reliability analysis, Confirmatory factor analysis (CFA) on the InCharge Financial Distress/Financial Well-Being Scale (IFDFW) and General Functioning Subscale of the McMaster Family Assessment Device (McMaster FAD) items was conducted. 


\section{A. Aydıner Boylu - G. Günay - C. Kılıç 11/4 (2019) 3385-3403}

For both the scales, the single-factor model was tested. The analysis results showed that there were modification indices regarding the association of some items with the others. The researcher consulted experts in the relevant area of study as to whether the items which were recommended to be modified were associated with each other or not, and the experts' opinions indicated that the modifications were theoretically justified. Based on these opinions, the researcher modified the association between items 2-3 and 5-6 on the IFDFW. After adding covariance terms between items, the final model approached to adequate fit $\left(X^{2} / d f=7.2, \mathrm{p}<0.05\right.$, $\mathrm{NFI}=0.98, \mathrm{NNFI}=0.97, \mathrm{CFI}=0.98, \mathrm{IFI}=0.98, \mathrm{RFI}=0.96, \mathrm{GFI}=0.94$, and $\mathrm{RMSEA}=0.072$ ).

Similarly, for the General Functioning Subscale, the researcher modified the association between items 4-8 and 7-11. After adding covariance terms between items, the single factor model fit the data well, $\left(X^{2} / d f=8.4, p<\right.$ $0.05, \mathrm{NFI}=0.95, \mathrm{NNFI}=0.95, \mathrm{CFI}=0.96, \mathrm{IFI}=0.96, \mathrm{RFI}=0.94, \mathrm{GFI}=0.94$, and RMSEA $=0.078$ ).

Although confirmatory factor analysis showed that $X^{2} / d f$ was high, a comprehensive evaluation of fit and error indices indicated that the model was compatible (Hu and Bentler 1999; Tabachnick and Fidell 2007).

\subsection{Data Analysis}

The socio-demographic data was summarized using frequencies and percentages. Averages and standard deviations for the IFDFW and McMaster FAD forms were calculated and validity and reliability analysis were performed. Then, in order to test whether the differences between dependent and independent variables were significantly statistical or not, One-Way Analysis of Variance (ANOVA) and Test for Importance of Difference between Two Averages (t-test) were used. If there were two options (gender, budgeting, saving, reason for borrowing) for independent variables, the difference was tested using the Test for Importance of Difference between Two Averages (t-test). In cases where there were more than two options (working status, marital status, family type, being in debt), it was tested using ANOVA. Where significant difference was found as a result of ANOVA analysis, a Multiple Comparison Test (LSD) was performed to determine the group or groups causing this difference and the results were recorded in tables (Büyüköztürk 2007).

To determine the level or amount and direction of the relationship between dependent and independent variables, a correlation analysis was performed. In this study, a Pearson correlation analysis and a multiple regression analysis were applied to see whether age, education level, family monthly income, number of family members, and IFDFW scale are effective on the general functioning dimension of the FAD scale (Büyüköztürk 2007). The researcher conducted a two-step regression analysis to distinguish the variance explained by financial distress from the variance explained by demographic variables and to test predictive power independently. In the first step of the regression analysis, the independent variables (age, monthly family income, education, and number of family members) were included to the regression equation, whereas the IFDFW was added to the model in the second step.

\section{Results}

A t-test analysis was performed to determine whether there was any relationship between gender and the General Functioning subscale of the FAD. An ANOVA analysis was performed to analyze the relationships among general functions and working status, marital status, and family type. The results are given in Table 4 .

According to Table 4, there was no statistically significant relationship between general family functioning and the gender of study participants $(t=1.910, d f=1398, p>0.05)$.

There was significant relationship between participant working status and general functions $(F=5.279, d f=$ $1395, p<0.001)$. According to the LSD test results, the differences were determined to be originating among the following groups: Academic staff $(M=1.3 ; S D=0.4)$, Administrative staff $(M=1.4 ; S D=0.4)$, and Auxiliary staff $(M=1.5 ; S D=0.4)$. However, the analysis concluded that the effect size was 0.02 . Thus, the significant correlation might have resulted from the size of the sample.

General family functioning was also significantly different among marital status subgroups $(F=8.840, d f=$ $1397, p<0.001)$, in particular, single parents $(M=1.5 ; S D=0.4)$ and married couples $(M=1.4 ; S D=0.4)$. However, the analysis concluded that the effect size was 0.01 . Thus, the significant correlation might have resulted from the size of the sample.

There was significance between the type of family and general functions $(F=9.460, d f=1397, p<0.001)$ from the nuclear family $(M=1.4 ; S D=0.4)$ and the extended family $(M=1.5 ; S D=0.4)$ and the nuclear family $(M=$ 


\section{A. Aydıner Boylu - G. Günay - C. Kılıç 11/4 (2019) 3385-3403}

1.4; $S D=0.4)$ and single parent families $(M=1.5 ; S D=0.5)$. However, the analysis concluded that the effect size was 0.01 . Thus, the significant correlation might have resulted from the size of the sample.

Table 4 Relationship Between Demographic Characteristics and The General Functioning Subscale

\begin{tabular}{lccccc}
\hline Demographic Variables & $N$ & $M$ & $S D$ & Statistical Test & Eta Squared \\
\hline Gender & 703 & 1.4 & 0.4 & & \\
$\quad$ Woman & 697 & 1.4 & 0.4 & $t=-1.910, d f=1398, p=.056$ & 0.05 \\
$\quad$ Man & & & & & \\
Working status & 468 & 1.3 & 0.4 & & \\
$\quad$ Academic staff & 621 & 1.4 & 0.4 & & \\
Administrative staff & 98 & 1.4 & 0.4 & $F=5.279, d f=1395, p=.000^{*}$ & \\
Technical staff & 26 & 1.4 & 0.4 & & \\
$\quad$ Medical staff & 187 & 1.5 & 0.4 & & \\
Auxiliary staff & & & & & \\
Marital status & 445 & 1.5 & 0.4 & & \\
$\quad$ Single & 906 & 1.4 & 0.4 & $F=8.840, d f=1397, p=.000^{*}$ & \\
$\quad$ Married & 49 & 1.5 & 0.5 & & \\
$\quad$ Widowed/Divorced & & & & & \\
Family type & 1247 & 1.4 & 0.4 & & \\
$\quad$ Nuclear family & 101 & 1.5 & 0.4 & $F=9.460, d f=1397, p=.000^{*}$ & \\
$\quad$ Extended family & 52 & 1.5 & 0.4 & & \\
$\quad$ Single parent family & & & &
\end{tabular}

${ }^{*} p<0.001 ;{ }^{* *} p<0.05 ;$ M:Mean; $S D$ : Standart deviation

A Pearson correlation analysis was performed to examine the relationships among demographic variables (age, monthly family income, education, and number of family members), financial distress (IFDFW), and general functions. The results of the Pearson correlation are given in Table 5, which illustrates a positive relationship between general family functions and monthly income level $(.11, p<0.01)$ and education level $(.14, p<0.01)$. There is a negative relationships at 0.01 levels among general family functions, the number of family members $(-.16, p<0.01)$, and financial distress $(-.15, p<0.01)$. In other words, as the monthly income levels and education levels increase, general family functions improve. When the number of family members and the financial distress increase, general family functions deteriorate.

According to the results, age and general family functioning were not significantly associated in this study. However, there was a significant relationship between income level and general family functioning. In this study families with higher monthly incomes reported better functioning. Significant associations were also observed for education level, whereby people with higher levels of education reported better functioning.

Based on the results of this study, general functions and the number of family members was statistically significant. Finally, financial distress does relate significantly to general family functioning. The increase in financial distress negatively affect general family functioning.

Table 5 Pearson Correlation of Demographic Characteristics, Financial Distress, and The General Functioning Subscale

\begin{tabular}{lllllll}
\hline Variables & $\mathbf{1}$ & $\mathbf{2}$ & $\mathbf{3}$ & $\mathbf{4}$ & $\mathbf{5}$ & $\mathbf{6}$ \\
\hline 1. Age & 1 & & & & & \\
2. Monthly family income &, $25^{* *}$ & 1 & & & & \\
3. Education &,$- 11^{* *}$ &, $64^{* *}$ & 1 & & & \\
4. Number of family members &, $6^{*}$ &,$- 12^{* *}$ &,$- 35^{* *}$ & 1 & & \\
5. IFDFW &,$- 07^{* *}$ &, $40^{* *}$ &, $38^{* *}$ &,$- 07^{*}$ & 1 & \\
6. General Functioning &, 01 &, $11^{* *}$ &, $14^{* *}$ &,$- 16^{* *}$ &,$- 15^{* *}$ & 1 \\
\hline
\end{tabular}

**. Correlation is significant at the 0.01 level (2-tailed).

*. Correlation is significant at the 0.05 level (2-tailed). 


\section{A. Aydıner Boylu - G. Günay - C. Kılıç 11/4 (2019) 3385-3403}

The relationship between financial behaviors of the participants and general functions of the families was analyzed and revealed a statistically significant difference between budgeting status and general functions $(t$ $=-2.572, d f=1398, p<0.05$ ) (Table 6). This significant difference came from families who do not follow a budget $(M=1.5 ; S D=0.4)$ and generated an inverse relationship. The analysis revealed that the effect size was 0.07 , indicating that this difference was not related to the sample.

The relationship between saving status and general functions was significant $(t=-3.350, d f=1398, p=.001)$ and came from the ones who do not save any of their income $(M=1.5 ; S D=0.4)$ (Table 6). In accordance to the study results, as expected saving is related to better general functioning. The analysis revealed that the effect size was 0.09 , indicating that this difference was not related to the sample.

There was no relationship between general family functions and borrowing $(F=1.149, d f=1397, p>0.05)$. However, there was a statistically significant relationship between the reasons for borrowing and general functions $(t=2.918, d f=1124, p<0.05)$. The analysis revealed that the effect size was 0.08 , indicating that this difference was not related to the sample. According to the LSD results, this significance arose from the difference between "maintaining current expenditures" $(M=1.4 ; S D=0.4)$ and "investing" $(M=1.4 ; S D=0.4)$ (Table 6).

Table 6 Relationship Between Financial Behaviors and The General Functioning Subscale

\begin{tabular}{lccccc}
\hline Financial Behaviors & $N$ & $M$ & $S D$ & Statistical Test & Eta Squared \\
\hline $\begin{array}{l}\text { Budgeting } \\
\text { Yes }\end{array}$ & 1038 & 1.4 & 0.4 & $t=-2.572, d f=1398, p=.010^{*}$ & 0.07 \\
$\quad$ No & 362 & 1.5 & 0.4 & & \\
Saving & 1027 & 1.4 & 0.4 & $t=-3.350, d f=1398, p=.001^{*}$ & 0.09 \\
$\quad$ Yes & 373 & 1.5 & 0.4 & & \\
$\quad$ No & & & & & \\
Being in debt & 916 & 1.4 & 0.4 & & \\
$\quad$ Yes & 210 & 1.4 & 0.4 & $F=1.149, d f=1397, p=.317$ & \\
$\quad$ Sometimes & 274 & 1.4 & 0.4 & & \\
$\quad$ No & & & & & \\
$\quad$ Reason for borrowing & 560 & 1.4 & 0.4 & $t=2.918, d f=1124, p=.040^{*}$ & 0.08 \\
$\quad$ Maintaining current & 566 & 1.4 & 0.4 & & \\
$\quad$ expenditure & & & &
\end{tabular}

${ }^{*} p<0.05 ;$ M:Mean; $S D$ : Standart deviation

Multiple regression analysis was used to examine the role of demographic and financial distress on the general family functioning in accordance with the purpose of the study. Results of the multiple regression analysis related to general family functions are given in Table 7. In the first step of the multiple regression analysis, age, monthly income, education level, and number of family members from the demographic variables were included. In the second step, financial distress level was included. By comparing the determination coefficients $\left(R^{2}\right)$ gained from these two steps, whether independent variables give information about general family functions was evaluated for these participants. Demographic variables (age, monthly family income, education, and number of family members) express $04 \%$ of total variance of general family functions $(R=0.2$, $\left.R^{2}=0.04, F=13.154, p<0.001\right)$. Regression coefficients standardized $(\beta)$ to test the effect of independent variables taking place in Model 1 on general family functions and t-test results related to significance are given in Table 7. The variance rate expressed related to demographic variables and financial distress was $05 \%(R=$ $\left.0.2, R^{2}=0.05, F=12.351, p<0.001\right)$. 
Table 7 Regression Analysis of Demographic Characteristics, Financial Distress, and The General Functioning Subscale

\begin{tabular}{|c|c|c|c|c|c|c|c|c|c|}
\hline & $B$ & $\beta$ & $t$ & $p$ & $R$ & $R^{2}$ & $R^{2}$ & $F$ & $p$ \\
\hline Step 1. & & & & & .2 & .04 & .03 & 13.154 & $.000^{*}$ \\
\hline & 1,296 & & & & & & & & \\
\hline 1. Age & 001 &, 026 & ,913 & 362 & & & & & \\
\hline 2. Monthly family income & 2,056 & 089 & 2,703 &, $007^{* *}$ & & & & & \\
\hline 3. Education & ,003 & 028 & ,878 & ,380 & & & & & \\
\hline $\begin{array}{l}\text { 4. Number of family } \\
\text { members }\end{array}$ &,- 050 &,- 144 & $-5,405$ &, $000^{*}$ & & & & & \\
\hline Step 2. & & & & & .2 & .05 & .05 & 12.351 & $.000^{*}$ \\
\hline & 1,490 & & & & & & & & \\
\hline 1. Age & 3.439 &, 001 & 028 & 977 & & & & & \\
\hline 2. Monthly family income & 8.785 &, 038 & 1,097 & ,273 & & & & & \\
\hline 3. Education & 001 &, 007 & ,228 & 820 & & & & & \\
\hline $\begin{array}{l}\text { 4. Number of family } \\
\text { members }\end{array}$ &,- 050 &,- 145 & $-5,454$ &, $000^{*}$ & & & & & \\
\hline 5. IFDFW &,- 018 &,- 095 & $-2,915$ &, $004^{* *}$ & & & & & \\
\hline
\end{tabular}

${ }^{*} p<0.001 ;{ }^{* *} p<0.05 ; B:$ Unstandardized regression coefficient; $\beta$ :Standardized regression coefficient; $t$ :Observed $t$ value; $p$ :Significance level; $R$ :Multiple $R ; R^{2}$ :Effect size; $R^{2}$.:Adjusted $R^{2} ; F$ : Observed $F ; p$ : Significance level

\section{Discussion}

This paper explored the relationship between financial distress and general family functioning in families and included the effects of demographic factors and financial behaviors of Turkish families. Results of the study showed that better family functioning is strongly associated with smaller households and lower levels of financial distress.

\subsection{Relationship Between Demographic Characteristics and The General Functioning Subscale}

There was no statistically significant relationship between general family functioning and the gender in the present study. These findings are in accordance with those of Krasnow (1995:58) but not Hossain (2001), which reports that mothers stated greater commitment, cohesion, and communication in the family than fathers. Similarly, Sylvanus (1992) found higher scores for women when compared to men. The present study findings can be explained by the positive aspects of mens' involvement in the family (e.g., problem solving, communication, roles). In other words men in this sample are involved in the family and are committed and competent in family functioning as much as women.

The significant relationship between participant working status and general functions can be explained by the fact that working status is related to income level and working conditions such as working day, working hours, flexibility of timetable, work load, safety, pressure on the worker. Hence working status effect the satisfaction with payment and work itself and also individual and family life satisfaction.

General family functioning was significantly different among marital status subgroups. However, in In the study by Krasnows (1995: 58), no significant differences were found between married and single (including divorced) parents in terms of family functions. Wang et al. (2015) showed that compared to other marital statuses, including separated, divorced, and widowed, married couples enjoy family life more and have higher happiness scores.

There was significance between the type of family and general functions in the present study. In various studies, differences were found in family functions according to family types (Nazlı 1997; İmamoğlu 1991; İnci 2008:42). In more culturally traditional family types, couples can seem to live in almost different worlds. They do not talk much about issues such as their children's development, private emotions and thoughts, sexual 


\section{A. Aydıner Boylu - G. Günay - C. Kılıç 11/4 (2019) 3385-3403}

life and health problems, social relations, or politics. The communication between couples in nuclear families is greater and more varied. İrmiş (1992) determined that the type of family is significantly related to family decision-making functions, the idea that a father knows best about everything related to the family is dominant, and other family members are not free to express their own ideas. These findings confirm the importance of a nuclear family in family functioning. Murdock (1949) explained, "... [T] he nuclear family is the basic form from which more complex familial forms are compounded... [It is] a distinct and strongly functional group in every known society". There are also data available in the literature that support the position that family functioning is better in two-parent families than in single-parent families (Clark et al. 2000; Yeung and Chan 2010). For example, Florsheim et al. (1998) and Pettit et al. (2001) found that parental monitoring level was lower in single-parent families than in two-parent families. Also, in a study conducted by Hayden et al. (1998), it was found that family functions were significantly lower in families where the head of the household was an unmarried mother.

\subsection{Pearson Correlation Between Demographic Characteristics, Financial Distress, and The General Functioning Subscale}

According to the results, as the monthly income levels and education levels increase, general family functions improve. When the number of family members and the financial distress increase, general family functions deteriorate.

Age and general family functioning were not significantly associated in the present study. This results are not confirmed by Ersoy (1997). Ersoy determined that the age of the woman in the family is significantly related to decision-making in the family, finding a solution for problems, and solving problems related to household management. This study result can be explained by the fact that age is not just the one indicator itself of being skilled and experienced on problem solving, communication, roles, affective responsiveness, affective involvement and behavior control.

In this study families with higher monthly incomes reported better functioning, which is confirmed by earlier studies (Duyan 2000:149; Sertelin 2003:126; Çakıc1 2006:92, Şimşek 2009; Kıliçaslan 2001:160). According to İnci (2008:45), general functions are improved with increases in income levels. In applied family studies and family disciplines, economic resources play an important role in family functioning. Adequate income is a very important protective factor for the family and has many benefits. Low-wage incomes and financial adversity have been associated with substance abuse, criminality, increased family stress, and child abuse and maltreatment, as well as cognitive and emotional deficits (Hutchings and Lane 2005; Lloyd and Rosman 2005; Skowron 2005; Jackson et al. 2000).

Significant associations were also observed for education level, whereby people with higher levels of education reported better functioning. Earlier studies also found a positive correlation between male and female educational backgrounds and general family functioning (Nazlı 1997; Çakıcı 2006:101-105; Şimşek 2009; İnci 2008:38). In these studies, parents with higher education levels were more compatible and open-minded, provided a more positive family atmosphere, and general family relationships were better. İmamoğlu (1991) observed that with an increase in education levels of couples, their roles shift to more equitable levels. The absence of a relationship between education level and general family functioning can be explained by the fact that individuals with higher education levels are expected to have better comprehension, listening and problem solving skills, and to be more understanding and democratic. In addition higher levels of education is related to earn more, promoted more quickly and better job, also is strongly positively associated with happiness and life satisfaction.

General functions and the number of family members was also statistically significant. These finding are confirmed by İnci (2008:42). İnci determined that, a significant relationship exists between the number of family members and the quality of general family functioning. This result shows that an increase in the number of family members has negative effects on many functions such as opportunities for self-expression and having time to deal with each family member. The number of family members affects role and communication stereotypes in families. Smaller family size eases communication and leads members to listen and understand each other. Hypothesis 1 of the study is supported by the variables; working status, marital status, family type, monthly family income, education, and number of family members but it is not supported by the variables, gender and age. 


\section{A. Aydıner Boylu - G. Günay - C. Kılıç 11/4 (2019) 3385-3403}

Finally, the increase in financial distress negatively affect general family functioning. These findings are confirmed by Aydıner Boylu (2014). Aydıner Boylu determined that the financial distress in single parent families were significantly correlated to general family functioning. Evidence shows the harmful effects of economic stress on family functioning and family relationships (Elder and Caspi 1988; Brody et al. 1995; Conger et al. 1990a, 1993; McLoyd 1990). Economic stress has been associated with a decrease in family satisfaction and cohesion (Voydanoff 1990). Gomel et al. (1998) found that family relationships suffered in times of economic stress, with greater perceived economic hardship resulting in poorer family relationships. Hypothesis 3 is supported as the relationship was significant.

\subsection{Relationship Between Financial Behaviors and The General Functioning Subscale}

Financial behaviors of the family are vital element of financial welfare (Çopur and Şafak 2000; Bailey 1987). In this study, financial behaviors measured by budgeting, saving, and borrowing behaviors produced results that showed significant relationships among maintaining a budget, saving income, the reason for borrowing money, and general family functioning, whereas no relationship was found between being in debt and the level of functioning.

There was significant difference between budgeting status and general functions in the present study. Godwin (1990) suggests that families' subjective financial well-being is more strongly related to their attitudes rather than their objectively measurable financial status. Hence budgeting is a crucial activities to diminish the families financial problems and also related to family functioning.

The relationship between saving status and general functions was also significant. Findings of this study are in line with those of Han and Rothwell (2014), who concluded that a reduction in savings was positively and significantly associated with family strain and that there were significant associations between family strain and family functioning. Saving is necessary to improve the economic welfare of families and lessen the impacts of financial hardships (Lee et al. 2000).

Whereas there was no relationship between general family functions and borrowing, there was a statistically significant relationship between the reasons for borrowing and general functions. Many families are forced to borrow money in the case of unexpected events or to attend to certain urgent matters, for example, illnesses, disabilities, and so on. Some families may also borrow money in order to maintain their existing lifestyle, for example, automobiles, house loans, education, and so on (Garman and Forgue 1988; Stillman 1988). Hence borrowing have different impacts on family functioning depending on the types and how used by families. According to the results of this study more than half of the families are borrowing to investing. This result is an indication that families are in debt to meet their desires and raise their living standarts which positively effect family functioning. Hypothesis 2 of the study is supported by the variables; budgeting, saving and reason for borrowing but it is not supported by the variable, being in debt.

\subsection{Regression Analysis of Demographic Characteristics, Financial Distress, and The General Functioning Subscale}

Considering the regression coefficients standardized $(\beta)$ in the study and the t-test results, it was determined that there is a significant difference between financial distress and general functions $(\beta=-.095, p<.05)$.

\section{Conclusions and Implications}

It is clear that financial behaviors are related to financial distress and important for maintaining better general family functioning. Therefore, it is necessary to understand the families in financial distress to maintain general family functioning. Further studies should investigate the causes and negative effects of financial distress as well as the psychological factors that are associated with reducing distress. These studies can help institutions and organizations to assist families in financial distress and provide guidance for the preparation of training programs designed to increase financial well-being. Recent literature indicates that the lack of financial management competency has a more significant influence on financial distress than income poverty (Kim and Garman 2003; Hilgert et al. 2003; Joo and Grable 2004; O'Neill et al. 2006; Ha and Kang 2013; Eom 2015; Kye and Yoo 2013). Financial literacy is an important foundation for strengthening financial management competency. Financial literacy is about understanding money and finances and being able to confidently apply this knowledge to make effective financial decisions (Australian Securities and Investments Commission 2011:4). This knowledge is also an important determinant of basic money management and financial planning 


\section{A. Aydıner Boylu - G. Günay - C. Kılıç 11/4 (2019) 3385-3403}

(Ali et al. 2015). Aldana and Liljenquist (1998) confirmed that the lack of financial education and understanding about financial matters is a significant determinant of financial strain (Porter and Garman 1993; Todd and DeVaney 1997).

This study has some limitations. Firstly, considering the cross-sectional research design of the study, a causal relationship between variables cannot be inferred. Future studies on this subject should be designed longitudinally in order to obtain more causal relationships between these variables. A second limitation is the methodological aspect of the study. The sample of the study was limited to Hacettepe University employees. This limits the generalizability of the results. Different groups (retired, unemployed, etc.) should be included in the sample of future studies. Finally, only one member from each family participated in the study. The participation of more members from each family may provide different findings. In addition, this study is limited by the General Functioning Subscale of the FAD. This study not investigate the relationship between financial distress and the other six subscales (problem solving, communication, roles, affective responsiveness, affective involvement, and behavior control). Further research in the specific areas of family functioning in the above subscales is required because the General Functioning Subscale is a global assessment tool for assessing a family's ability to accomplish basic, everyday tasks across domains, which include information from each of the domains but are not necessarily a linear combination of functions in specific areas. Further research is needed to address this issue.

\section{References}

Aldana, S.G. and Liljenquist, W. (1998). Validity and Reliability of A Financial Strain Survey, Financial Counseling and Planning, 9, 11-18.

Ali, A., Rahman, M.S.A. and Bakar, A. (2015). Financial Satisfaction and The Influence of Financial Literacy in Malaysia, Social Indicators Research, 120, 137-156.

Australian Securities and Investments Commission (2011). National Financial Literacy Strategy, Report 229, Australian Securities and Investments Commission, Sydney.

Aydıner Boylu, A. (2014). Tek Ebeveynli Ailelerde Finansal Sıkıntı ve Fonksiyonlar Arasındaki İlişkinin İncelenmesi, Hacettepe Üniversitesi İktisadi ve İdari Bilimler Dergisi, 32(1), 55-72.

Aydıner Boylu, A. and Günay, G. (2013). Examination of Socio-Economic Variables Having Effect on Functions of Single Parent Families, International Journal of Education and Research, 1(4), 1-10.

Aydıner Boylu, A., Günay, G. and Terzioğlu, G. (2007). Ailelerin Bankalarca Sağlanan Tüketici Kredilerini Kullanma Durumlarını İncelenmesi, Hacettepe Üniversitesi Sosyolojik Araştırmalar E-dergisi, Published online 15 August 2007.

Aytaç, I.A. and Rankin, B.H. (2008). Unemployment, Economic Strain and Family Distress: The Impact of The 2001 Economic Crisis, New Perspectives on Turkey, 38, 181-203.

Bailey, A.W. (1987). Social and Economic Factors Affecting the Financial Welfare of Families, Journal of Home Economics, 79(2), 4-18.

Beavers, R. and Hampson, R.B. (2000). The Beavers Systems Model of Family Functioning, Journal of Family Therapy, 22, 128-143.

Beutler, I.F. and Mason, J.W. (1987). Family Cash-Flow Budgeting, Home Economics Research Journal, 16, 3-12.

Bilen, M. (2004). Saglıklı İnsan İlişkileri, Ankara, Anı Yayıncılık.

Botha, F. and Booysen, F. (2014). Family Functioning and Life Satisfaction and Happiness in South African Households, Social Indicators Research, 119(1), 163-182.

Brody, G.H., Stoneman, Z. and Flor, D. (1995). Linking Family Processes and Academic Competence Among Rural African-American Youth, Journal of Marriage and Family, 57, 567-579.

Bulut, I. (1990). Aile Değerlendirme Ölçeği El Kitabı, Ankara, Özgüzeliş Matbaası.

Bulut, I. (1993). Ruh Sağlığının Aile İşlevlerine Etkisi, Sosyal Bilimler Dergisi, 61. 


\section{A. Aydıner Boylu - G. Günay - C. Kılıç 11/4 (2019) 3385-3403}

Büyüköztürk, Ş. (2007). Sosyal Bilimler Için Veri Analiz El Kitabı, Ankara, Pegem Akademi Yayıncılık.

Byles, J., Byrne, C., Boyle, M.H. and Offord, D.R. (1988). Ontario Child Health Study: Reliability and Validity of The General Functioning Subscale of The McMaster Family Assessment Device, Family Process, 27, 97-104.

Clark, A.F., Barrett, L. and Kolvin, I. (2000). Inner City Disadvantage and Family Functioning, European Child $\mathcal{E}$ Adolescent Psychiatry, 9(2), 77-83.

Conger, R.D., Conger, K.J., Elder, G.H., Lorenz, F.O., Simons, R.L. and Whitbeck, L.B. (1992). A Family Process Model of Economic Hardship and Adjustment of Early Adolescent Boys, Child Development, 63, 526541.

Conger, R.D., Elder, G.H., Lorenz, F.O., Conger, K.J. and Simons, R.L. (1990a). Linking Economic Hardship To Marital Quality and Instability, Journal of Marriage and Family, 52, 643-656.

Conger, R.D., Rueter, M.A. and Elder, G.H. (1990b). Couple Resilience To Economic Pressure, Journal of Personality and Social Psychology, 76, 54-71.

Çakıcı, S. (2006). Alt ve Üst Sosyoekonomik Düzeydeki Ailelerin Aile İşlevlerinin, Anne-Çocuk İlişkilerinin ve Aile İşlevlerinin Anne-Çocuk İlişkilerine Etkisinin İncelenmesi, Gazi Üniversitesi Çocuk Gelişimi ve Eğitimi Ana Bilim Dalı yüksek lisans tezi, Ankara.

Çopur Z. and Şafak, Ş. (2000). Ailede Gelirin Kullanımına İlişkin Karşılaşılan Problemlerin İncelenmesi, Aile ve Toplum, 2(6), 7-14.

Danes, S.M. and Rettig, K.D. (1995). Economic Adjustment Strategies of Farm Men and Women Experiencing Economic Stress, Financial Counseling and Planning, 6, 59-73.

Davis, E.P. and Schumm, W.R. (1987). Savings Behavior and Satisfaction With Savings: A Comparison of Low and High Income Groups, Home Economics Research Journal, 15, 247-256.

Dodge K.A., Pettit G.S. and Bates J.E. (1994). Socialization Mediators of The Relation Between Socioeconomic Status and Child Conduct Problems, Child Development, 65, 649-665.

Drumm, M., Carr, A. and Fitzgerald, M. (2000). The Beavers, McMaster and Circumplex Clinical Rating Scales: A Study of Their Sensitivity, Specificity and Discriminant Validity, Journal of Family Therapy, 22, 225238.

Duyan, G.Ç. (2000). Aile İşlevleri ile Ailenin Sosyal, Demografik, Ekonomik Nitelikleri ve Yaşam Döngüsü Arasındaki İlişkiler, Hacettepe Üniversitesi Sosyal Hizmet Anabilim Dalı yüksek lisans tezi, Ankara.

Elder, G.H., Nguyen, T. and Caspi, A. (1985). Linking Family Hardship To Children's Lives, Child Development, $56,361-375$.

Elder, G.H. and Caspi, A. (1988). Economic Stress in Lives: Developmental Perspectives, Journal of Social Issues, $44,25-45$.

Elder, G.H., Conger, R.D., Foster, E.M. and Ardelt, M. (1992). Families Under Economic Pressure, Journal of Family Issues, 13, 5-37.

Eom, T.W. (2015). The Effects of Self-Efficacy and Social Support in The Relationship Between Economic Stress and Depression of The Indigent Population, Metal Health \& Social Work, 28(4), 97-129.

Epstein, N.B., Bishop, D.S. and Levin, S. (1978). The McMaster Model of Family Functioning, Journal of Marriage and Family Counseling, 4, 19-31.

Epstein, N.B., Bishop, D S. and Baldwin, L.M. (1982). McMaster Model of Family Functioning: A View of The Normal Family. In F. Walsh (Ed.), Normal family processes (pp.138-160), New York, Guilford Press.

Epstein, N.B., Bishop, D.S. and Baldwin, L.M. (1984). McMaster Model of Family Functioning. In D.H. Olson, \& P.M. Miller (Eds.), Family Studies Review Yearbook, Volume 2, New Delhi, Sage Publications.

Epstein, N.B., Baldwin, L.M. and Bishop, D.S. (1983). The McMaster Family Assesment Device, Journal of Marital and Family Therapy, 9(2):171-180. 
A. Aydıner Boylu - G. Günay - C. K1lıç 11/4 (2019) 3385-3403

Ersoy, A.F. (1997). Aile İçi Etkilesim ve Ailede Meydana Gelen Bazı Sorunlar Üzerine Bir Araştırma, Türkiye Sosyal Araştırmalar Dergisi, 127-139.

Fine, M.A. and Fincham, F.D. (2013). Handbook of family theories. A Content-Based Approach, New York, Routledge.

Fişek, G. (1992). Aile Yazıları 3: Birey Kişilik ve Toplum, Türk Ailesinin Dinamik ve Yapısal Özellikleri Üzerine Düşünceler ve Konuya İlişkin Bir Ön Çalışma, Ankara, Başbakanlık Aile Araştırma Kurumu.

Florsheim, P., Tolan, P. and Gorman-Smith, D. (1998). Family Relationships, Parenting Practices, The Availability of Male Family Members, and The Behavior of Inner-City Boys in Single-Mother and TwoParent Families, Child Development, 69(5):1437-1447.

Fox, G.L., Benson, M.L., DeMaris, A.A. and Wyk, J.V. (2002). Economic Distress and Intimate Violence: Testing Family Stress and Resources Theories, Journal of Marriage and the Family, 64, 793-807.

Friedman, J. and Thomas, D. (2009). Psychological Health Before, During and After An Economic Crisis: Results From Indonesia, 1993-2000, World Bank Economic Review, 23(1), 57-76.

Garman, E.T. and Forgue, R.E. (1988). Personal Finance, Boston, Houghton Mifflin Company.

Garman, E.T., Sorhaindo, B., Kim, J., Xiao, J.J., Bailey, W. and Prawitz, A. (2004). The Development of The Beta Version of The InCharge Financial Distress Scale. Consumer Interests Annual, 50. July 6. www.consumerinterests.org/i4a/pages/Index.cfm?pageid=3892

Gelles, R.J. (1989). Child Abuse and Violence in Single-Parent Families: Parent Absence and Economic Deprivation, American Journal of Orthopsychiatry, 59, 492-501.

Gelles, R.J. and Straus, M.A. (1979). Violence in The American Family, Journal of Social Issues, 35, 15-39.

Gershoff, E., Aber, L., Raver, C. and Lennon, M. (2007). Income is Not Enough: Incorporating Material Hardship Into Models of Income Associations With Parenting and Child Development, Child Development, 78, 70-95.

Godwin, D.D. (1990). Family Financial Management, Family Relations, 39, 221-228.

Gomel, N.J., Tinsley, B.J., Parke, R.D. and Clark, K.M. (1998). The Effects of Economic Hardship on Family Relationships Among African, American, Latino, and Euro-American Families, Journal of Family Issues, 19, 436-467.

Gökçe, B. (1990). Aile Yazıları 1: Aile ve Aile Tipleri Üzerine Bir İnceleme, Ankara, Başbakanlık Aile Araştırma Kurumu Başkanlığı Yayınları.

Gutter, M.S. and Copur, Z. (2011). Financial Behaviors and Financial Well-Being of College Students: Evidence From A National Survey, Journal of Family and Economic Issues, 32(4), 699-714.

Günay, G., Aydıner Boylu, A. and Bener, Ö. (2014). An Examination of Factors Affecting Economic Status and Finances Satisfaction of Families: A Comparison of Metropolitan and Rural Areas, Social Indicators Research, 119(1), 211-245.

Ha, K.H. and Kang, B.C. (2013). A Qualitative Research on Psychological Distress of Poor Households, Korean Journal of Qualitative Research on Social Welfare, 7(2), 115-137.

Han, C.K. and Rothwell, D.W. (2014). Savings and Family Functioning Since The 2008 Recession: An Exploratory Study in Singapore, International Social Work, 57(6), 630-644.

Hashima, P.Y. and Amato, P.R. (1994). Poverty, Social Support and Parental Behavior, Child Development, 65(2), 394-403.

Hayden L.C., Schiller, M., Dickstein, S., Seifer R., Sameroff, A.J., Miller, I., Keitner, G. and Rasmussen, S. (1998). Levels of Family Assessment: Family, Marital, and Parent-Child Interaction, Journal of Family Psychology, 12(1), 7-22.

Hilgert, M., Hogarth, J. and Beverly, S. (2003). Household Financial Management: The Connection Between Knowledge and Behavior, Federal Reserve Bulletin, 89, 309-322. 
A. Aydıner Boylu - G. Günay - C. K1lıç 11/4 (2019) 3385-3403

Ho, C.S., Lempers, J.D. and Clark-Lempers, D.S. (1995). Effects of Economic Hardship on Adolescent SelfEsteem: A Family Mediation Model, Adolescence, 30, 117-131.

Hossain, Z. (2001). Division of Household Labor and Family Functioning in Off-Reservation Navajo Indian Families, Family Relations, 50(3), 255-261.

Hu, L. and Bentler, P.M. (1999). Cutoff Criteria For Fit Indexes In Covariance Structure Analysis: Conventional Criteria Versus New Alternatives, Structural Equation Modeling, 6(1), 1-55.

Hutchings, J. and Lane, E. (2005). Parenting and the Development and Prevention of Child Mental Health Problems, Current Opinion in Psychiatry, 18, 386-391.

İmamoğlu, O. (1991). Aile İçinde Kadın ve Erkek Rolleri. Aile Kurultayı, Ankara, Aile Araştırma Kurumu Yayını.

İnci, H. (2008). Meslek Gruplarına Göre Aile İçi Fonksiyonların Araştırılması, Fatih Üniversitesi Tıp Fakültesi Aile Hekimliği Anabilim Dalı yayınlanmamış yüksek lisans tezi, Ankara.

İrmiş, A. (1992). Kararlara Katılma ve Kararlara Katılmada Ailenin Rolü, Atatürk Üniversitesi Yüksek Lisans Tezi, Erzurum.

Jackson, A., Brooks-Gunn, J., Chien-Chung, H. and Glassman, M. (2000). Single Mothers in Low-Wage Jobs: Financial Strain, Parenting, and Preschoolers' Outcomes, Child Development, 71, 1409-1423.

Joo, H. and Grable, J.E. (2004). An Exploratory Framework of The Determinants of Financial Satisfaction, Journal of Family and Economic Issues, 25, 25-50.

Karasar, N. (2007). Bilimsel Araştırma Yöntemi, Ankara, Bilim Kitap Kırtasiye Yayınevi.

Kaya, K. (2002). Ekonomik Krizin Yaşama Tarzı Üzerindeki Etkileri: Isparta Örneği, Süleyman Demirel Üniversitesi İktisadi ve İdari Bilimler Dergisi, 7(2), 207-226.

Kılıçaslan, A. (2001). Aile Fonksiyonlarının ve Algılanan Farklılaşmış Anne-Baba Yaklaşımının Kardeş İlişkileri Üzerindeki Etkisi, İstanbul Üniversitesi Sosyal Bilimler Enstitüsü Eğitim Bilimleri Anabilim Dalı yayınlanmamış yüksek lisans tezi, İstanbul.

Kim, J. and Garman, E.T. (2003). Financial Stress and Absenteeism: An Empirically Derived Model, Financial Counseling and Planning, 14(1), 31-42.

Krasnow, M. (1995). Strength-Based Family Assessments. A Paradigm Shift Utilizing A Family Functioning Scale To Identify Strengths, USA, UMI Company.

Kye, S.J. and Yoo, E.Y. (2013). Urban Housewives' Family Financial Management Ability and Financial Satisfaction, Korean Family Resource Management Association, 3, 35-50.

Lee, S., Myung-Hee, P. and Montalto, C. P. (2000). The Effect of Family Life Cycle and Financial Management Practices on Household Saving Patterns, Journal of Korean Home Economics Association, 1(1), 79-94.

Lempers, J.D., Clark-Lempers, D. and Simons R.L. (1989). Economic Hardship, Parenting, and Distress in Adolescence, Child Development, 60, 25-39.

Lempers, J.D. and Clark-Lempers, D.S. (1997). Economic Hardship, Family Relationship, and Adolescent Distress: An Evaluation of A Stress-Distress Mediation Model in Mother-Daughter and Mother-Son Dyads, Adolescence, 32, 339-356.

Lewis, J.M., Beavers, W.R., Gosselt, J.T. and Philips, V.A. (1976). No Single Thread: Psychological Health in Family Systems, New York, Brunner/ Mazel.

Liker, J.K. and Elder, G.H. (1983). Economic Hardship and Marital Relations in The 1930s, American Sociological Review, 48, 343-359.

Lloyd, C.M. and Rosman, E. (2005). Exploring Mental Health Outcomes For Low-Income Mothers of Children With Special Needs: Implications For Policy and Practice, Infants \& Young Children, 18, 186-199.

Mandara, J. and Murray, C.B. (2000). Effects of Parental Marital Status, Income, and Family Functioning On African American Adolescent Self-Esteem, Journal of Family Psychology, 14(3), 475-490. 
A. Aydıner Boylu - G. Günay - C. K1lıç 11/4 (2019) 3385-3403

McCreary, L.L. and Dancy, B.L. (2004). Dimensions of Family Functioning: Perspective of Low Income African American Single-Parent Families, Journal of Marriage and Family, 66(3), 690-701.

Mcloyd, V. (1990). The Impact of Economic Hardship On Black Families and Children. Psychological Distress, Parenting and Socioemotional Development, Child Development, 61, 311-346.

McLoyd, V.C. and Wilson, L. (1991). The Strain of Living Poor: Parenting, Social Support, and Child Mental Health. In A.C. Huston (Ed.), Children in poverty: Child development and public policy, (pp.105-135), New York, Cambridge University Press.

Miller, I.W., Bishop, D.S., Epstein, N.B. and Keitner, G.I. (1985). The Mcmaster Family Assessment Device: Reliability and Validity, Journal of Marital and Family Therapy, 11(4), 345-356.

Murdock, P.M. (1949). Social Structure, New York, Free Press.

Nazlı, S. (1997). Aile Fonksiyonlarının Bazı Değişkenlere Göre İncelenmesi, Gazi Üniversitesi Eğitim Bilimleri Enstitüsü Eğitimde Psikolojik Hizmetler Anabilim Dalı yayınlanmamış doktora tezi.

Olson, D.H. (2000). Circumplex Model of Marital and Family Systems, Journal of Family Therapy, 22, 144-167.

O'Neill, B., Prawitz, A.D., Sorhaindo, B., Kim, J. and Garman, E.T. (2006). Changes in Health, Negative Financial Events, and Financial Distress/Financial Well-Being For Debt Management Program Clients, Financial Counseling and Planning, 17(2), 46-63.

Ormsby, P. and Fairchild, T.G. (1987). Perceived Income Adequacy and Selected Financial Management Practices Among Families in Chile and Mexico, Social Indicators Research, 19, 317-327.

Papp, L.M., Cummings, E.M. and Goeke-Morey, M.C. (2009). For Richer, For Poorer: Money As A Topic of Marital Conflict in The Home, Family Relations, 58(1), 91-103.

Pettit, G.S., Laird, R.D., Dodge, K.A., Bates, J.E. and Criss, M.M. (2001). Antecedents and Behavior-Problem Outcomes of Parental Monitoring and Psychological Control In Early Adolescence, Child Development, 72(2):583-598.

Pittman, J.F. and Lloyd, S.A. (1988). Quality of Family Life, Social Support and Stress, Journal of Marriage and the Family, 50, 53-67.

Porter, N.M., \& Garman, E.T. (1993). Testing a Conceptual Model of Financial Well-Being, Financial Counseling and Planning, 4, 135-164.

Prawitz, A.D., Garman, T E., Sorhaindo, B., O’Neill, B., Kim, J. and Drentea, P. (2006). The InCharge Financial Distress/Financial Well-Being Scale: Development, Administration, and Score Interpretation, Financial Counseling and Planning, 17(1), 34-50.

Ryan, C.E., Epstein, N.B., Keitner, G.I., Miller, I.W. and Bishop, D.S. (2005). Evaluating and Treating Families: The McMaster Approach, New York, Routledge.

Sertelin, Ç. (2003). Ebeveyn Tutumlarının Sosyo-Kültürel Yapı ve Aile Fonksiyonları ile İlişkisi. İstanbul Üniversitesi Sosyal Bilimler Enstitüsü Eğitim Bilimleri Anabilim Dalı yayınlanmamış yüksek lisans tezi, İstanbul.

Skowron, E.A. (2005). Parent Differentiation of Self and Child Competence in Low-Income Urban Families, Journal of Counseling Psychology, 52, 337-346.

Stillman, RJ. (1988). Guide to Personal Finance, New Jersey, Prentice Hall.

Sumarwan, U. and Hira, K.T. (1993). The Effects of Perceived Locus of Control and Perceived ncome Adequacy on Satisfaction With Financial Status of Rural Households, Journal of Family and Economic Issues, 14(4), 343-364.

Sylvanus, U.J. (1992). Effects of Early İntervention on Family Functioning. [Online] Available: https://shareok.org/bitstream/handle/11244/18434/Thesis-1992D-U48e.pdf?sequence=1\&isAllowed=y (December 20, 2011). 
A. Aydıner Boylu - G. Günay - C. K1lıç 11/4 (2019) 3385-3403

Şimşek, H.B. (2009). Ankara'nın Farklı Sosyo-Ekonomik Bölgelerinde Yaşayan Aile Bireylerinin Aile İlişkilerini Algılama Durumları, Gazi Üniversitesi Endüstriyel Sanatlar Eğitim Fakültesi Dergisi, 25, 8-26.

Tabachnick, B.G. and Fidell, L.S. (2007). Using Multivariate Statistics, Boston, Pearson Education Inc.

Todd, K.J. and DeVaney, S.A. (1997). Financial Planning for Retirement by Parents of College Students, Financial Counseling and Planning, 8, 25-32.

Tschann, J.M., Johnston, J.R. and Wallerstein, J.S. (1989). Resources, Stressors, and Attachment as Predictors of Adult Adjustment After Divorce: A Longitudinal Study, Journal of Marriage and the family, 51, 10331046.

Voydanoff, P. (1990). Economic Distress and Family Relations: A Review of The Eighties, Journal of Marriage and the family, 52, 1099-1115.

Walsh, P. (2003). Changing Families in A Changing World: Reconstructing Family Normality. In F. Walsh (Ed.), Normal family processes: Growing diversity and complexity (3rd ed.), (pp.3-26), New York, Guilford York.

Walson, C.O. and Fitzsimmons, V.S. (1993). Financial Manager's Perception of Rural Household Economic Well-Being: Development and Testing of A Composite Measure, Journal of Family and Economic Issues, 14(3), 193-215.

Wang, P., Pan, J. and Luo, Z. (2015). The Impact of Income Inequality on Individual Happiness: Evidence from China, Social Indicators Research, 121, 413-435.

Xiao, J.J. (2008). Handbook of Consumer Finance Research. In J.J. Xiao (Ed.), Applying behavior theories in financial behaviors, (pp.69-81), New York, Springer.

Yeung, J.W.K. and Chan, Y. (2010). Family Functioning of Chinese Families in an Impoverished Neighborhood in Hong Kong, Psychological Reports, 107(3),740-748. 